\title{
Anthropomorphism or Becoming-animal? Ka- shiang Liu's Hill of Stray Dogs as a Case in Point
}

Tsung-Huei Huang

\section{(2) OpenEdition}

\section{Journals}

\section{Electronic version}

URL: http://journals.openedition.org/transtexts/279

DOI: $10.4000 /$ transtexts.279

ISSN: 2105-2549

\section{Publisher}

Gregory B. Lee

\section{Printed version}

Date of publication: 1 June 2009

ISSN: 1771-2084

\section{Electronic reference}

Tsung-Huei Huang, « Anthropomorphism or Becoming-animal? Ka-shiang Liu's Hill of Stray Dogs as a Case in Point », Transtext(e)s Transcultures 跨文本跨文化 [Online], 5 | 2009, document 9, Online since 08 April 2010, connection on 30 April 2019. URL : http://journals.openedition.org/transtexts/279 DOI : $10.4000 /$ transtexts. 279 


\title{
Transtext(e)s Transcultures 跨文本跨文化
}

Journal of Global Cultural Studies

$5 \mid 2009:$

Varia

Varia

\section{Anthropomorphism or Becoming- animal? Ka-shiang Liu's Hill of Stray Dogs as a Case in Point}

\author{
TSUNG-HUEI HUANG
}

\section{Résumé}

In this paper, I will use Ka-shiang Liu's Hill of Stray Dogs as case in point to examine how he presents stray dogs' behaviors, their language, and even their unconscious. I will engage with the questions as follows: is Liu's animal writing in tune with the concept of becoming-animal which Gilles Deleuze and Félix Guattari advocate? If for Deleuze and Guattari animals operate "more as a device of writing" than as living beings whose conditions of life are of direct concern to the writers, ${ }^{1}$ does Liu go beyond their limitation and succeed in "giving visible form to what is animal in the animal"?2 To put it another way, does Liu's animal writing pave the way for human beings to see animals as what Jacques Derrida calls "the seeing other"? In short, this paper would seek to deal with the question concerning whether we human beings can ever let the animal-other speak without running the risk of anthropocentric ventriloquism. 


\section{Texte intégral}

\section{Introduction}

Seeking to challenge anthropocentrism, animal writers often manage to interpret the language of animals or endow them with a voice of their own, so as to deepen our understanding of non-human animals. ${ }^{3}$ However, since it is debatable whether non-human animals have languages, we may wonder if their efforts of interpretation/representation are ultimately to no avail. Actually, even when we admit that animals can engage in cognitive or communicative activities, there is still the risk that the verbalization is "for the speaker's own benefit in that it is central to constructing a dialogue like exchange with the animal." 4 Under such circumstances, it stands to reason that we should thoroughly examine the writer's mode of "speaking for" so as to determine whether he is just rendering "a discourse of man," which remains "an anthropomorphic taming, a moralizing subjection, a domestication." 5 In this paper, I will use Ka-shiang Liu's 劉克襄 Hill of Stray Dogs as a case in point to investigate how Liu gives voice to what he understands to be the perspective of the strays. ${ }^{6}$ With a view to address the relations between humans and animals, this paper proposes to bring Liu's animal concern in dialogue with contemporary theorists' dealings of animals.

In his novella, Liu not only describes stray dogs' behaviors like an ethologist, he also enables them to express their thoughts and even unearths their unconscious. Does this kind of animal writing realize the possibility of "becoming animal" that Deleuze and Guattari advocate, in which "it is no longer the subject of the statement who is a dog, with the subject of the enunciation remaining 'like' a man", but "a circuit of states that forms a mutual becoming"-the becoming-dog of the man and the becoming-man of the dog?7 To answer the question, I will explore Liu's animal writing as well as the Deleuzo-Guattarian idea of becoming-animal to see if they can shed light on each other. Notwithstanding that becoming-animal is "freed from the human organism's interested and organizing perception", ${ }^{8}$ Deleuze and Guattari's main concern is not so much animals' conditions of life as the human's own desire for freedom. ${ }^{9}$ Therefore, in addition to identifying the correspondences between Liu's writing and the concept of becoming-animal, I will discuss how Liu's treatment and representation of stray dogs reveal that the idea in question is limited in scope.

Thirteen years ago, Taipei City Government implemented a new garbage disposal policy, which required all residents to place out their trash on the scheduled pickup time. Under the impact of this policy, the food sources of stray dogs were largely reduced, and it became harder and harder for them to survive in the harsh environment. In the same year, the City 
resorted to the methodology of high volume killing to control populations of stray dogs. While these policies seem prerequisites for the modernization of the city, in an article against the culling program, Liu maintains that stray dogs are also citizens. He does not go so far as to claim that stray dogs control is unnecessary; what Liu disapproves is the anthropocentric ideology which underlies the culling program: "valorizing safety and hygiene of the city, we ignore the fact that the city does not exclusively belong to human beings; what is more,we fail to reflect on the historical determinants that bring strays into existence."10 Basically, Hill of Stray Dogs retains his concern for stray dogs. As Liu states in the epigraph, the book is executed in memory of the strays that were killed at that time. Yet unlike the article "Strays Dogs Have Been out of Sight for Twelve Years," which is a straightforward outcry against strays eradication, Hill of Stray Dogs is multi-faceted, revealing the writer's perspective as well as the dogs'. The setting of the novella is a hill in the neighborhood of Liu's dwelling, where a number of stray dogs inhabit. Liu focuses on twelve of them to recount the story of their life. With the aid of the monocular telescope, Liu had been watching them from afar for 655 days and incessantly writing in his journal the observations of them. The novella in its present form is mainly based on extracts from Liu's journal. ${ }^{11}$ Although "anthropomorphophobia"12 is a common occurrence among animal writers and artists, Liu does not shy away from depicting dialogues between dogs, and he even deliberately compares their behaviors to those of human beings. ${ }^{13}$ Yet it is not to say that Liu's writing is tantamount to an endorsement of anthropomorphism. ${ }^{14}$ Rather, as I am going to argue, he is attempting to "write like a dog," namely, to "become animal."

Before bearing out my argument that Liu's animal writing is in consonant with Deleuze and Guattari's philosophy, I will elaborate their idea of becoming-animal and account for how it may serve to open up the possibility for disrupting anthropocentrism. According to Deleuze, to write like an animal "does not mean writing about one's dog, one's cat, one's horse or one's favorite animal," nor does it mean "making animal speak." Rather, it means "writing as a rat traces a line, or as it twists its tail, as a bird sends out a sound, as a cat moves or else sleeps heavily." 15 However, this is not to say that the writer is supposed to imitate the animals' movements. It is not through imitation that the writer is able to enter the "relations of movement and rest, speed and slowness" of the animal. ${ }^{16}$ Only when the writer is affected by the affecting animal can he become animal "in an original assemblage proceeding neither by resemblance nor by analogy." 17 Notably, Deleuze and Guattari's definition of the term "affect" is different from its original meaning in psychoanalytic terminology. By L'affect they mean "a prepersonal intensity corresponding to the passage from one experiential state of the body to another." 18 As the affects are "puissances, powers of affecting and being affected", 19 they are essential for charting the encounter between different beings. ${ }^{20}$ And when one allows one's original identity to be swept away by the intensities of the other, one may thereby deterritorialize into the other. The famous Deleuzo-Guattarian wasp-orchid assemblage is exactly an exemplar of the mutual 
deterritorialization. ${ }^{21}$ Similarly, when the human is fascinated by what Deleuze and Guattari call "pack or affect animals", ${ }^{22}$ having liberated himself from the limited perception, he will be able to undo his identity to join with the animal:

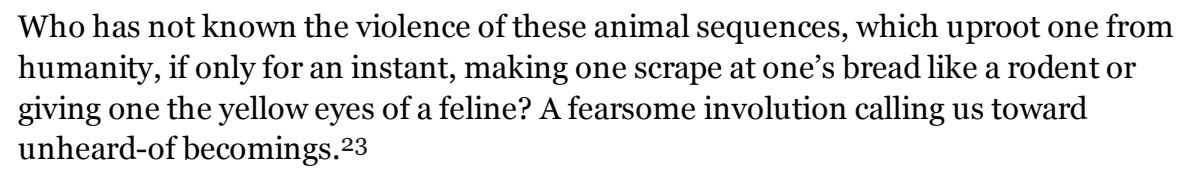

Deleuze and Guattari also apply their concept of becoming-animal to reinterpret Freud's cases such as Wolf-Man or little Hans. While Freud sees Wolf-Man's fear of wolves as triggered by the traumatic primal scene, Deleuze and Guattari suggest that actually he is "fascinated by several wolves watching him." ${ }^{24}$ It is the "wolfing", 25 or, "the non-familial, non-individual (or pack-like) wandering of the wolves which attracts the wolf-man." ${ }^{26}$ Likewise, defying Freud's analysis that the horse with blinders represents Hans's father and the heavily loaded horse, the pregnant mother, ${ }^{27}$ Deleuze and Guattari see in Hans the reality of a becoming-animal that "is affect in itself, the drive in person, and represents nothing." 28 Being drawn to "what a horse 'can do", little Hans mounts an assemblage with the horse "in order to solve a problem from which all exits are barred him." ${ }^{29}$ In this light, when Freud reads Hans's phobia as "phantasies or subjective reveries", $3^{\circ}$ he ignores it is the positivity of desire that enables Hans to "participate in movement" of the horse and "to stake out the path of escape." 31

Following Deleuze and Guattari's concept of becoming, we will find that the established view of the body is also challenged, for the reason why one can be affected by the other is because every organ "is exactly what its elements make it according to their relation of movement and rest, and the way in which this relation combines with or splits off from that of neighboring element." 32 A body is no longer defined by "Species or Genus characteristics"; rather, it is determined by what it can do, by "what its affects are, how they can or cannot enter into composition with other affects, with the affects of another body." 33 To be more specific, a body is defined only by "the sum total of the material elements belonging to it under given relations of movement and rest, speed and slowness (longitude)" and "the sum total of the intensive affects it is capable of at a given power or degree of potential (latitude)." 34 Moreover, it is not merely the living organism that can make its conjunction with others. Even "[c]limate, wind, season, hour are not of another nature than the things, animals, or people that populate them, follow them, sleep and awaken within them." 35 Take the statement "the animal stalks at five o'clock" for example. When we parse this statement, we tend to bring the subject, "the animal," to the forefront. But for Deleuze and Guattari, "the animal-stalks-at-five-o'clock" "should be read without a pause": "Five o'clock is this animal! This animal is this place!" 36 In other words, each being is inseparable from its milieu. ${ }^{37}$ Like a rhizome made of intersecting lines, a being is a concrete individuation traversed by the spatiotemporal components, a mode of life that is 
determined "by haecceity than by subjectivity or substantiality." 38 Under such circumstances, we are no longer distinguished "from all of the becomings running through us", 39 and the privileged standpoint of human being, accordingly, will be destabilized:

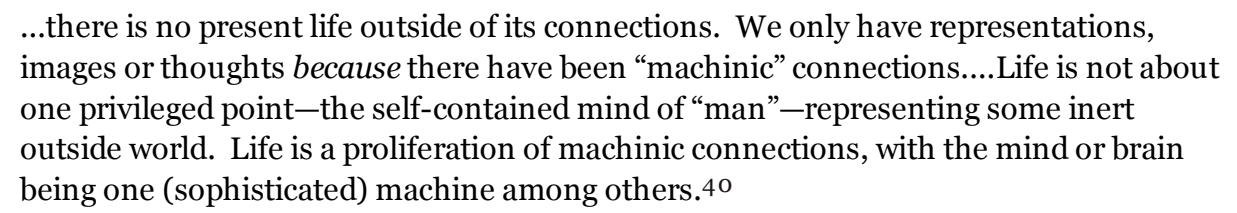

7 However, man is not always willing to develop the creative potentialities of becoming. In fact, since the power of the affecting other "throws the self into upheaval and makes it reel", ${ }^{41}$ if we are not ready to be deterritorialized by these forces, the experience of encountering the other may arouse our anxiety or even fear of annihilation. But the Deleuzo-Guattarian writer, as the "sorcerer," "has a very particular relation to the animal," and thus may "enter the privileged 'experimental' state of identity-suspension which they call becoming-animal." ${ }^{22}$ To put it succinctly, the Deleuzo-Guattarian writer's concern with creative invention and his ability to undo his identity allow him to enact the becoming, to "emit corpuscles that enter the relation of movement and rest of the animal particles, or what amounts to the same thing, that enter the zone of proximity of the animal molecule." 43

Liu Ka-shiang's animal writing, to a great extent, verifies the Deleuzo-Guattarian thesis that "becomings are not phenomena of imitation or assimilation" but a conversation, or, a matter of conjunction. ${ }^{44}$ Liu enters into the movement of becoming animal by commencing a conversation with stray dogs, which enables him to probe into their behavior as well as their mental states. As I have suggested, the Deleuzo-Guattarian writer is responsive to the fascinating multiplicity of pack animals. What must be added is that it is "always with the Anomalous" that one "enters into alliance to become-animal." 45 The anomalous is "the borderline" that enables the writer "to understand the various positions it occupies in relation to the pack or the multiplicity it borders." 46 Being fascinated by the affects of the anomalous, the writer is able to tie his writing to the new becoming. In Hill of Stray Dogs, the protagonist Little Winter Melon functions as the anomalous that leads Liu into his becoming-dog. As Liu states in the afterword, the way this pregnant dog shuttles between the hill and the scrap yard at the foot of the hill attracts Liu's attention, and her movements, her relations with other stray dogs thus constitute the centerpiece of this novella. The first part of the novella is mainly about how Little Winter Melon nurtures her progeny, Potato and Teeny, and coaches them to survive in a harsh environment. The whole book, as a matter of fact, centers around her breeding behavior and ends with her giving birth to the fifth litter of pups. Notably, Liu does not attempt to grace Little Winter Melon by depicting her as a mother dog that would fight to the death to keep her offspring alive. Sometimes she nurses the pups without crouching over them, 
shortening the breastfeeding time as much as she can; sometimes she even deliberately refuses her breast to them. ${ }^{47}$ And when Little Winter Melon leads her young to embark on their search for food, she walks fast without paying attention to Teeny, the weaker one that straggles behind. ${ }^{48}$ Liu then explains the maternal indifference he witnesses from an ethological perspective: the aloofness of the mother makes sense because the pups must adapt themselves to the uncertain environment as early as possible if they want to make their way in the rocky world on their own. 49

This is not to say that Liu's book is little more than a record of his observations of stray dogs. Nor does he seek to analyze all their behaviors as if he could explicate every action pattern the strays display. As Liu affectively inhabits the strays' milieu by integrating the spatiotemporal relations, which "are not predicates of the thing but dimensions of multiplicities", $5^{\circ}$ much multiplicity is lent to his objective account of their routine activities such as foraging, eating, seeking refuge, etc. Liu affectionately depicts the strays' differences in terms of their movements and shows in detail how each stray, as an assemblage that is "inseparable from an hour, a season, an atmosphere, an air", ${ }^{11}$ is traversed by the spatiotemporal components. The pup plays with its sibling in the morning, the dog rests in the shade at noon and searching for food in the scrap yard after midnight, ${ }^{22}$ the mother dog shelters in the shrubs with her pups during rainy days and buries her young when they freeze to death in winter, etc.53The narrative of this kind is not so much a litany of behavior observations as a description of the becoming-noon, becoming-night, or becoming-winter of the strays. It is not too much of a distortion to argue that the concrete individuation that Deleuze and Guattari champion finds a loud echo in Liu's writing.

Moreover, Liu does not confine his descriptions of strays to the "movements in extension," namely, their trajectories. He captures as well their "movements in 'intension'," the intensive forces that subtend the trajectories. 54 Without involving himself in the philosophical debate about "whether one has the right to refuse the animal such and such a power (speech, reason, experience of death, mourning, culture, institution, technics, clothing, lie, pretense of pretense, covering of tracks, gift, laughter, tears, respect, and so on"55, Liu directly affirms the strays' ability to mourn and to experience death by depicting how Protein laments the death of her pup. When Protein's pup is run over by a car and finally died, she holds its dead body in her mouth and drops it in front of a grocery store, hoping that the shopkeeper who used to feed them may bury her puppy. But since the accident happens in the early morning, the store is not yet open. Then a passer-by finds the dead puppy disgusting and throws it into a trash can. This very act leaves the mother dog in despair; all she can do is staying around the trash can and sniffing it unceasingly. ${ }^{6}$ Taking up Protein's position to express grief on her behalf, Liu calls attention to the animal's capability of mourning by representing its movement in intension.

The temptation to charge Liu with anthropocentric ventriloquism seems irresistible when we find Liu attempts to surmise how Protein laments the death of her pup. However, 
as Deleuze contends,

In writing one always gives writing to those who do not have it, but the latter give writing a becoming without which it would not exist.... That the writer is minoritarian ... means that writing always encounters a minority which does not write, and it does not undertake to write for this minority, in its place or at its bidding, but there is an encounter in which each pushes the other, draws it on to its line of flight in a combined deterritorialization. Writing always combines with something else...This is not a matter of imitation, but of conjunction. 57

In other words, if the writer maintains a stance that is "[n]either identification nor distance, neither proximity nor remoteness," he will be able to "speak with, write with" the minority without silencing it..$^{8}$ Since Liu's "objective" accounts and "subjective" descriptions are always already interpenetrated, 59 he steers clear of "the two traps of distance and identification," namely, "the one which offers us the mirror of contamination and identifications, and the one which points out to us the observation of the understanding." 60 Sometimes Liu reports on a series of mishaps that befall on the strays like a journalist, but what underlies the ostensibly objective descriptions is the writer's deep concern and sympathy for the strays. ${ }^{61}$ In other cases, while the writer seems to be reading the stray's mind arbitrarily, it turns out that the interpretation is based on his long-lasting observation. ${ }^{62}$ It is next to impossible to separate his objective descriptions from subjective interpretations, for Liu, to put it in Deleuzian terms, is "neither simulator of identifications nor the frigid doctor of distance." ${ }_{3}$ As Deleuze cautions the writer, when writing with the other, "you do not need to mistake yourself for him. But you may perhaps put yourself in his shoes, you have something to assemble with him." ${ }^{64}$ Fascinated by the multiplicity of the strays without thereby identifying himself with them, Liu writes with the strays by becoming animal.

Deleuze and Guattari claim that becoming-minoritarian "is a political affair and necessitates a labor of power, an active micropolitics." ${ }^{65}$ Its political aim, to put it simply, is to subvert the "binary machines" such as "question-answer, masculine-feminine, man-animal, etc." ${ }^{66}$ As the concept of becoming-animal binds the writer and the animal with each other, its political efficacy lies "in the unthinking or undoing of the conventionally human." 67 Revealing of Liu's efforts to undo anthropocentric binarism are the analogies he constantly draws between human beings and strays. Mating behavior of the strays is likened to courtship between men and women at parties. ${ }^{68}$ The way Crazy Black Hair guards Protein and their pups is so civilized and moving that Liu believes the male dog can be compared to a human father. ${ }^{69}$ While antianthropomorphic thinkers may 
find these descriptions misleading, I contend that if anthropomorphic statements are derived from "introspection, reasoning by analogy, interpretive analysis, and intuition", ${ }^{\circ}$ or, if the mental predicates are assigned to an animal "on the basis of the situation and behavior of the animal", ${ }^{11}$ they may even further our understanding of animals. As John Andrew Fisher rightly observes, anthropomorphism, referring to "thinking in human terms about an object that is not human," is almost used in a negative sense. The charge of anthropomorphism is not unconditionally justifiable, however. If we ascribe to animals the characteristics only humans have or even project onto them cultural stereotypes, such anthropomorphic identifications indeed smack of anthropocentrism..$^{72}$ On the other hand, "if we assign to nonhumans human properties that those nonhumans also have, we have not made a mistake."73 Some ethologists even suggest that "critical anthropomorphism" may serve as a useful heuristic device for us to understand animal behavior. ${ }^{74}$ Gordon M. Burghardt, for example, claims that critical anthropomorphism enables us "to pose and formulate questions and hypotheses about animal behavior" even though we can never experience directly what the animal thinks or feels. ${ }^{75}$ In this sense, we may say that Liu's critical anthropomorphism is not so much the outcome of his subjective projection as the product of deterritorialization. Being deterritorialized by the force of stray dogs, Liu situates the boundaries human beings and the strays without deliberately shunning anthropomorphism.

Liu does not simply undo the human/nonhuman animal dichotomy by anthropomorphic inferences. His concern for the welfare of animals drives him to radically challenge our biases against stray dogs and further, to question if it is justified to assume them as intruders in the city. While a raft of people believe stray dogs would pose direct threat to passers-by, Liu notes that the dogs involved in incidents of attacks are usually pet dogs, especially the large and powerful breeds such as pit bulls and Rottweilers. ${ }^{76}$ While the authorities claim that stray dogs must be eliminated for the well-being of city residents, Liu finds dog culling to be a perpetual and futile cycle since culled areas are quickly repopulated by unsterilized and newly abandoned strays. ${ }^{77}$ Moreover, unlike those who allege that stray dogs disrupt the quality of life, Liu does not assume the menace of stray dogs to citizens as a hard-wired affair. On the contrary, in his narration, sometimes it is the human that catches the strays off guard by intruding into their dwelling places. ${ }^{78}$ Witnessing how strays manage to adapt themselves to human society, he poignantly questions why they are not entitled to citizenship and why they have to undergo such merciless culling. 79 If for Deleuze and Guattari there is a much higher concern in writing than animal concern ${ }^{80}$ and thus "what becoming-animal does is close to what art does", 81 Liu's becoming-animal, more than a mere rhetoric, moves toward the animal more closely by touching on the subject of animal rights. ${ }^{82}$

In fact, for Deleuze and Guattari, the immanent end of writing is not becoming-animal but becoming-imperceptible. ${ }^{83}$ To become imperceptible, that is, to "go unnoticed", 84 
anticipates the possibility of communicating and assembling with others:

By process of elimination, one is no longer anything more than an abstract line, or a piece in a puzzle that is itself abstract....To reduce oneself to an abstract line, a trait, in order to find one's zone of indiscernibility with other traits, and in this way enter the haecceity and impersonality of the creator. One is then like grass: one has made the world, everybody/everything, into a becoming, because one has made a necessarily communicating world, because one has suppressed in oneself everything that prevents us from slipping between things and growing in the midst of things. ${ }^{85}$

Given that becoming-imperceptible presupposes the elimination of "'all that is waste, death, and superfluity,' complaint and grievance, unsatisfied desire, defense of pleading, everything that roots each of us (everybody) in ourselves", ${ }^{86}$ we have reasons to believe that somehow it will bring forth the disruption of anthropocentrism. In other words, since becoming's movement away from the Oedipal human self "unhumans the human," to a certain extent it suggests a moving toward the animal. ${ }^{87}$ However, what Deleuze and Gauattari seek to highlight in becoming-animal is not so much the animal per se as "the power of literature", ${ }^{88}$ for they contend that the writer "can be thrown into a becoming by anything at all, by the most unexpected, most insignificant things." 89 To be more specific, as long as "the unexpected" can prompt one to find "a creative line of escape", 90 it doesn't matter what kind of animal it is:

To become animal is to participate in movement, to stake out the path of escape in all its positivity, to cross a threshold, ... to find of world of pure intensities where all forms come undone, as do all the significations, signifiers, and signifieds, to the benefit of an unformed matter of deterritorialized flux, of nonsignifying signs. There is no longer anything but movements, vibrations, thresholds in a deserted matter: animals, mice, dogs, apes, cockroaches are distinguished only by this or that threshold, this or that vibration, by the particular underground tunnel in the rhizome or the burrow. 91

It goes without saying that for Deleuze and Guattari becoming-animal is simply one of the means the writer adopts to cope with the rigid Oedipal structure. In fact, they rarely advocate the concept of becoming-animal without qualifications. For example, they do not rest content with Kafka's "Metamorphosis," commenting disapprovingly that Gregor's becoming-animal ends up in "a becoming-dead" when his deterritorialization is blocked by the urge to be re-Oedipalized..$^{2}$ Further, they imply that Gregor's deterritorialization fails through no fault of his own:

Isn't it rather that the acts of becoming-animal cannot follow their principle all the way through - that they maintain a certain ambiguity that leads to their insufficiency and condemns them to defeat? Aren't the animals still too formed, too significative, too territorialized? Doesn't the whole of becoming-animal oscillate between a schizo escape and an Oedipal impasse?93 
As I have said, Deleuze and Guattari classify the animal world into three categories, and prefer demonic animals, i.e., pack animal, on the ground that they give the writer's imagination the freest scope. Given that the primary aim of becoming is to divert from the Oedipal trajectory and to undo the conventional significations, the animal that is "too formed, too significative, too territorialized" simply will not do. Little wonder that they would rather construe the animal as "animal molecule"94; be it a rat, a horse, a bird or a cat, the animal in question has to become "something else, bloc, line, sound, colour of sand-an abstract line" so as to combine with other molecules.95 Moreover, as Baker rightly observes, in "putting the animal to work against the forces of Oedipalization, Deleuze and Guattari's writing reserves particular contempt for those upsetting aberrations," namely, the "animal which is too much like a human." 96 On the question of the animal, Liu sharply differs from Deleuze and Guattari in the aforementioned aspects. To sum up, in Liu's writing, how the writer may trace a creative line of escape through the animal molecule matters little; what is at stake is how the animal itself can find an escape in the human society. Further, while Deleuze and Guattari, in favor of the demonic, wild animals, disparage domestic animals for their lack of multiplicity, ${ }^{97}$ Liu aligns them with creative possibilities. ${ }^{8}$ In my conclusion, I will draw on Steve Baker's modification of becoming-animal to show how Liu displays the multiplicity of stray dogs through both written and visual representations.

\section{Conclusion}

The Hill of Stray Dogs includes about fifty pictures taken by Liu, and each picture is properly captioned to illustrate the variegated activities of the strays. Much in the line of the artists who feel slightly apprehensive about Deleuze and Guattari's "seductive but elusive ideas" of becoming-animal, Liu attends to the animals' "existence . . . their dignity and their beauty" by recording "the animal's reality." 99 As Baker notices, "becomingsanimal are increasingly evident in contemporary art."100 Nevertheless, some postmodern artists' use of animal imagery, instead of foregrounding their animal concern, is merely to serve the aesthetic purpose. In this way, they follow the Deleuzo-Guattarian becominganimal without challenging it. Among those who seriously engage with the question of the animal and prove themselves able to add a new dimension to the practice of becominganimal, Baker finds Olly and Suzi particularly impressive, for they deliberately allow animal-made marks a vital role to play in their oeuvre: "wherever it is possible without too much manipulation of the situation, they allow the animals depicted in their work to 'interact' with the work and mark it further themselves." ${ }^{101}$ What is more important is that their work intends "above all to bring home the truth and immediacy of these animals' precarious existence to a Western audience which has grown largely indifferent to the 
question of the endangered species."102 As his like-minded artists, Liu aims at "giving visible form to what is animal in the animal"103 and proposes to direct our attention to stray dogs' precarious existence in the city. Liu's work is "marked by the animal" in the sense that the abundant photographs of the strays operate in the visual domain to supplement his narrative, and even to prick readers in the manner of the punctum. Observing the photograph in which two little girls look at a primitive airplane above their village, Ronald Barthes ponders, "[t]hey have their whole lives before them; but also they are dead (today), they are then already dead (yesterday)."104 The "catastrophe which has already occurred" is what Barthes calls the punctum of intensity, the "lacerating emphasis of the noeme ("that-has-been"). In Liu's work, the vivid images of the strays display the same intensity: no sooner had we readers exclaimed "how alive the strays are!" than we shuddered at the thought of their "death in the future."105 Literally speaking, the strays fail to make any mark upon Liu's work. However, as the insertion of photographs not only witnesses the strays' presence but reminds us of "that-has-been," each stray in the story leaves a singular trace that cannot possibly be erased.

Notably, to represent "what is animal in the animal" does not mean to capture every aspects of the animal in question as if the author were omniscient. On the contrary, it is only when "the idea of human completeness disappears" that the artist may "enable the viewer to glimpse and perhaps even to be swept up in something of the animal's difference and distance from the human." 106 To put it simply, humility is the major requisite for the artist to create a work that sloughs off anthropocentric understanding of the animal. In Baker's opinion, Britta Jaschinski is one of those who excel in "discouraging anthropomorphic identifications." 107 The images of animals in her photographs are often obscure or even unrecognizable; her gibbon photograph, Hylobates lar, for example, is sometimes mistaken for a frog. While the unfocused images in her photographs are prone to disorient the viewer, somehow they "show the animals keeping knowledge of their bodies to themselves, and refusing to be easily drawn out about what it is that they are."108 Much in the similar vein, Liu constantly reminds us how dogs' behaviors are beyond comprehension of human beings. ${ }^{109}$ It has to be recognized, according to Liu, that we human beings can never correctly decipher the communications among dogs. ${ }^{110}$ In order to awaken readers to "the animal's unavailability to the human", ${ }^{111}$ whenever the dialogues between the strays find their way into the narrative, Liu lays great store on the fictionality of the constructed scenes. ${ }^{112}$ Having neither a conscious interest in the philosophical concept of become-animal nor a zest for postmodern art, Liu charts the animal's line of flight from the human in a less tortuous, but not less effective way. The Hill of Stray Dogs, therefore, exemplifies how "interpreting for the animal or explaining his or her experiences and feelings" can be "intended to promote the interests of the animal", ${ }^{113}$ and how animal writers can let the animal-other speak without necessarily running the risk of anthropocentric ventriloquism. 


\section{Notes}

1 Steve Baker, «What Does Becoming-Animal Look Like? », in Nigel Rothfels, ed., Representing Animals, Bloomington, Indiana University Press, 2002, p. 95.

2 Baker, pp. 95-96.

3 This paper was funded by a grant from National Science Council of Taiwan (NSC 96-2628$\mathrm{H}-002-074-\mathrm{MY}_{3}$ ); the project title is "Seeing Animal Others through/beyond the Psychoanalytic Speculum."

4 Arnold Arluke and Clinton R. Sanders, Regarding Animals, Philadelphia, Temple University Press, 1996, p. 67.

5 Jacques Derrida, tr. David Wills, «The Animal That Therefore I am (More to Follow) », Critical Inquiry, vol. 28, winter 2002, p. 405.

6 Ka-shiang Liu, Hill of Stray Dogs 野狗之丘, Taipei, Yuanliou Publishing Co., Ltd., 2007.

7 Gilles Deleuze and Félix Guattari, tr. Dana Polan, Kafka: Toward a Minor Literature, University of Minnesota Press, 1986, p. 22.

8 Claire Colebrook, Gilles Deleuze, London, Routledge, 2002, p. 129.

9 Baker, p. 95 .

10 Ka-shiang Liu, «Strays Dogs Have Been out of Sight for Twelve Years » 野狗消失十二年, Chine Times, 28 Jan 2006, A19.

11 Though Liu makes some modifications of the dogs' fates, he claims in the afterword that almost ninety percent of the novella is based on facts. See Liu, Hill of Stray Dogs, p. 191.

12 Steve Baker coins the word to refer to philosophers and postmodern artists' fear of sentimentality: "a fear that they may be accused of uncritical sentimentality in their depiction or discussion of animals." See Steve Baker, The Postmodern Animal, London, Reaktion Books, 2000, p. 175.

13 For example, Liu makes an analogy between pet dogs and upper-class ladies. Much as the ladies occupy themselves with shopping to squander time and money, pet dogs stroll around the streets to while time away simply because they don't have to forage for food as laboriously as the strays. See Liu, p. 18. Besides, Liu compares the relationship between the male dog Crazy Black Hair and the female dog Protein to that of an intimate couple and constantly translates their "body language" into human speech.

14 However, I would not object to construing Liu's animal writing as in tune with "critical anthropomorphism." The distinction between anthropomorphism and critical anthropomorphism will be addressed later.

15 Gilles Deleuze and Claire Parnet, tr. Hugh Tomlinson and Barbara Habberjam, Dialogues, New York, Columbia University Press, 1987, p. 75.

16 Gilles Deleuze and Félix Guattari, tr. Brian Massumi, A Thousand Plateaus: Capitalism and Schizophrenia, Minneapolis, University of Minnesota Press, 1987, p. 260.

17 Deleuze and Guattari,p. 258.

18 Deleuze and Guattari, xvi.

19 Ronald Bogue, Deleuze on Literature, New York, Routledge, 2003, p.171.

20 Deleuze and Guattari's understanding of "being" sharply diverges from that of humanists; for them 
"there 'is' nothing other than the flow of becoming. All 'beings' are just relatively stable moments in a flow of becoming-life." See Colebrook, pp. 125-126. The related concepts such as flow of becoming, fluxes, or the body "defined only by a longitude and a latitude", will be clarified later. See Deleuze and Guattari, p. 260.

21 To explain the becoming as a conjunction rather than an imitation, Deleuze uses the "double capture" of "the wasp AND the orchid." See Deleuze and Parnet, p. 7, for illustration: while the orchid seems to reproduce an image of the bee, in a deeper way it deterritorializes into the bee, and "the bee in turn deterritorializes by joining with the orchid." That is, their resemblance is not so much a matter of imitation as a result of being deterritorialized by each other's forces. See Deleuze and Félix Guattari, Kafka: Toward a Minor Literature, p. 14.

22 Deleuze and Guattari, $A$ Thousand Plateaus, p. 241. Deleuze and Guattarihave distinguished three kinds of animals, namely, Oedipal animals, State animals, and "more demonic animals, pack or affect animals that form a multiplicity, a becoming, a population, a tale...." In their opinion, the last one largely outweighs the other two in terms of its ability to effectuate becomings. What must be added is that "the animal as band or pack" cannot be understood literally as animals living in pack. By pack animal they refer to the animal that contains heterogeneous elements to connect with other beings, namely, the animal whose multiplicity fascinates us because it is "related to a multiplicity dwelling within us." For detailed definitions of the three kinds of animals, see Deleuze and Guattari, pp. 239-243.

23 Deleuze and Guattari, p. 240.

24 Deleuze and Guattari, p. 239.

25 Deleuze and Guattari, p. 239.

26 Colebrook, p. 135.

27 Interpreting the symbol of the horse in this way, Freud fulfills his purpose of relating Hans's phobia to the Oedipus complex. According to Freud, Hans's fear of the falling horse reveals two layers of meanings: he is afraid that his father might fall down because of his hostility toward him; on the other hand, given that the falling of the heavily loaded horse symbolizes a childbirth, a delivery, he is also afraid of the mother in childbirth. See Sigmund Freud, tr. and ed. James Strachey, Standard Edition of the Complete Works of Sigmund Freud: Two Case Histories,vol. X, London, Hogarth Press, 1987.

28 Deleuze and Guattari, p. 259.

29 Deleuze and Guattari, pp. 257-260.

30 Deleuze and Guattari, p. 258.

31 Deleuze and Guattari, Kafka: Toward a Minor Literature, p. 13.

32 Deleuze and Guattari, $A$ Thousand Plateaus, p. 256.

33 Deleuze and Guattari, p. 257.

34 Deleuze and Guattari, p. 260. For Deleuze and Guattari, longitude and latitude correspond to the extensive and the intensive respectively. For example, "a body that is cold here and hot there" depends on its longitude; that is, it is determined by how it is mapped spatially. See Deleuze and Guattari, p. 261. As for the intensive latitude, it is "not objectifiable and quantifiable as a thing that we then perceive or of which we are conscious" but pre-personal perception or presupposed intention that "happens to us, across us." See Colerook, p. 39. For example, in the case of "certain white skies of a hot summer", we find a degree of heat combining "in latitude with an intensity of white." See Deleuze and Guattari,p. 261.

35 Deleuze and Guattari, p. 263. 
36 Deleuze and Guattari, p. 263.

37 Take little Hans's case as an example again: in his becoming horse, Hans is not just forming a block with the horse; he enters the spatiotemporal relations as well. The family rooms, the streets, the warehouse across the street, the street-boys, the furniture-vans, etc., all these components of the milieu are combined with little Hans's qualities and affects. See Bogue, p.171; Deleuze and Gauttari, p. 263.

38 Deleuze and Guattari, p. 261. "Haecceity" is a term coined by Duns Scotus to refer to the distinctive qualities of the thing that make it particular. As Deleuze and Guattari explains, haecceity is "sometimes written 'ecceity,' deriving the word from ecce, 'here is." Given that this word is created "from haec, 'this thing", it is obviously an error to interchange haecceity with ecceity. However, Deleuze and Guattari call it a "fruitful error because it suggests a mode of individuation that is distinct from that of a thing or a subject". See Deleuze and Guattari, pp. 540-541. In other words, "here is" is closer to Deleuze and Guattari's understanding of haecceity. For them, all beings are actually haecceities "in the sense that they consist entirely of relations of movement and rest between molecules or particles, capacities to affect and be affected." To put it another way, all beings are "unformed particles, a set of nonsubjectified affects" before they are stabilized temporarily within a certain space. See Deleuze and Guattari, pp. 260-262.

39 Deleuze and Guattari, p. 240.

40 Colebrook, p.56.

41 Deleuze and Guattari, p. 240.

42 Baker, «What Does Becoming-Animal Look Like? », pp. 67-68. Actually, for Deleuze and Guattari, writing itself is a becoming "traversed by strange becomings that are not becomings-writer, but becomings-rat, becomings-insect, becomings-wolf, etc.” See Deleuze and Guattari, p. 240.

43 Deleuze and Guattari, pp. 274-275.

44 Deleuze and Parnet, p. 2 and p. 44.

45 Deleuze and Guattari, p. 244.

46 Deleuze and Guattari, p. 245.

47 Liu, Hill of Stray Dogs, p. 39 and p. 44.

48 Liu, p. 31.

49 Liu, p. 31 and p. 39.

50 Deleuze and Guattari, p. 263.

51 Deleuze and Guattari, p. 262.

52 Liu, p. 38.

53 Liu, p. 45 and p. 130.

54 Bogue, p. 171.

55 Jacques Derrida, tr. David Wills, " And Say the Animal Responded? ", in Cary Wolfe, ed., Zoontologies: The Question of the Animal, Minneapolis, University of Minnesota Press, 2003, p. 137. Lacan proposes that while man, the subject of signifier, can pretend to pretend, the animal is only capable of the first degree of pretense: "an animal does not feign feigning. It does not make tracks whose deceptiveness lies in getting them to be taken as false, when in fact they are true-that is, tracks that indicate the right trail." See Jacques Lacan, tr. Bruce Fink, Écrits, New York, W. W. Norton Company, 2006, p. 683. Taking the contrary position, Derrida argues that as long as it is impossible to 
distinguish between a feint and a feint of a feint in animals' sexual parade or mating game, "every pretense of pretense remains a simple pretense, or else, on the contrary, and just as likely, that every pretense, however simple it may be, gets repeated and reposited undecidably, in its possibility, as pretense of pretense." See Derrida, p. 135. Derrida also refutes the "naïve philosophy of the animal world" which asserts that "animals are incapable of keeping or even having a secret." See Jacques Derrida, " How to Avoid Speaking: Denials », in Harold Coward and Toby Foshay, eds., Derrida and Negative Theology, Albany: SUNY Press, 1992, pp. 86-87. According to Derrida, be it an animal or a man, "the self is essentially constituted by an endless detour on its way back to itself." Therefore, we have no reasons to believe that the animal "cannot return to itself" because it lacks "the power to reflect or to pose the question of Being." See Henry Staten, "Derrida and the Affect of Self », Western Humanities Review, vol. 50, $\mathrm{n}^{\circ} 4$-vol. 51, $\mathrm{n}^{\circ}$ 1, p. 348. However, Derrida's insistence on reconsidering all the boundaries between man and animal is also questioned by other theorists. For example, Jean-Luc Nancy asks, "When you decide not to limit a potential 'subjectivity' to man, why do you then limit yourself simply to the animal?” See Jacques Derrida, «'Eating Well,' or the Calculation of the Subject: An Interview with Jacques Derrida », in Eduardo Cadava, Peter Connor, and Jean-Luc Nancy, eds., Who Comes After the Subject?, New York, Routledge, 1991, p. 106. Likewise, while Derrida contends that the capacity to mourn is not exclusively the essential characteristic of the human subject, Henry Staten wonders, “wouldn't there still be an essential distinction, if not between human and animal, at least between animals that mourn (such as chimpanzees, and perhaps dogs) and animals that do not, or that we suppose do not?" See Staten, p. 351.

56 Liu, p. 166.

57 Deleuze and Parnet, p. 44.

58 Deleuze and Parnet, p. 52, original emphasis.

59 Liu himself concedes in the afterword that he has no idea whether this work should be classified as a novella or reportage literature. He would like to leave the question for scholars to answer. See Liu, p. 191.

6o Deleuze and Parnet, pp. 52-53.

61 Even though Liu manages to speak in a neutral tone, it grieves the writer to see the strays being violently killed by human beings. See Liu, p. 167, for example.

62 For example, Liu once found the stray he names Beansprout behaved weirdly-she rushed to and forth in the alley, wandering restlessly in the rain without trying to find a shelter. Even though he cannot possibly give voice to the dog's genuine subjective experience, he convinces the reader that the abnormal behavior results from the dog's sense of frustration and the anxiety in her unconscious. See Liu, p. 47. It is his observation of her behavior that enables him to provide such a plausible explanation: According to Liu, Beansprout appears unsettled because another pet dog's delivery completely occupies her owner. Unlike the pet dog pampered by her owner, Beansprout is a stray adopted later; as a latecomer, she is anxious that she will be ignored or even chased away since from now on her owner has to take care of the new born puppies. It is evident that for Liu, to imagine the animal's desire or unconscious is by no means ridiculous.

63 Deleuze and Parnet, pp. 53-54.

64 Deleuze and Parnet, p. 53.

65 Deleuze and Guattari, A Thousand Plateaus, p. 292.

66 Deleuze and Parnet, p. 2.

67 Baker, The Postmodern Animal, p. 104.

68 Liu, p. 98 and pp. 158-159. 
69 Liu, p. 151.

70 Arluke and Sanders, p. 80.

71 John Andrew Fisher, "Anthropomorphism», in Marc Bekoff and Carron A. Meaney, eds., Encyclopedia of Animal Rights and Animal Welfare, Westport, Greenwood Press, 1998, pp. 70-71.

72 Disneyfication, for example, represents the negative version of anthropomorphism. In Disney movies, animal characters are often deformed to resemble humans and thereby to entertain the audience: "This is achieved by showing them with humanlike facial features (eyebrows, expressive lips) and altered forelimbs to resemble human hands." See Slavoljub Milekic, "Disneyfication ", Encyclopedia of Animal Rights and Animal Welfare, p. 133.

73 Fisher, p. 70.

74 Arluke and Sanders, p. 80.

75 Gordon M. Burghardt, « Critical Anthropomorphism », Encyclopedia of Animal Rights and Animal Welfare, p. 72.

$76 \mathrm{Liu}$, p. 184.

77 Liu, p. 147.

78 Liu, p. 112 and p. 127.

79 Liu, p. 72, p. 152, and p. 172.

8o Deleuze and Guattari, Kafka: Toward a Minor Literature, p. 15.

81 Baker, «What Does Becoming-Animal Look Like?», p. 74.

82 Liu does not commit himself to animal rights campaign and has some reservations about the way the volunteer caregivers handle the problems of stray dogs. However, as he states in the afterword, the owners' merciless abandonment of their pets and the barbaric act of stray culling make the following questions occupy the forefront of his mind: What are stray dogs thinking about? Don't they have rights? How does a city treat its strays? See Liu, p.190.

83 As Deleuze claims, "[T] Negro-becoming, an animal-becoming, etc., beyond a minority-becoming, there is the final enterprise of the becoming-imperceptible." See Deleuze and Parnet, p. 45.

84 Deleuze and Guattari, $A$ Thousand Plateaus, p. 279.

85 Deleuze and Guattari, p. 280.

86 Deleuze and Guattari, p. 279.

87 Baker, p. 80 and p. 86.

88 Colebrook, p. 136.

89 Deleuze and Guattari, p. 292, emphasis added.

90 Deleuze and Guattari, Kafka: Toward a Minor Literature, p. 36.

91 Deleuze and Guattari, p. 13, emphasis added.

92 Deleuze and Guattari, p. 15 and p. 36.

93 Deleuze and Guattari, p. 15.

94 Deleuze and Guattari, $A$ Thousand Plateaus, p. 275.

95 Deleuze and Parnet, p. 75. Deleuze uses the Cheshire cat in Alice in Wonderland as an example to 
reassert his contention that "man only becomes animal if the animal, for its part, becomes sound, colour, or line": as Lewis Carroll indicates, "it is when the smile is without a cat that man can effectively become cat as soon as he smiles." See Deleuze and Parnet, p. 73.

96 Baker, The Postmodern Animal, p. 119 and p. 125.

97 Deleuze and Guattari label domestic animals as "family pets, sentimental, Oedipal animals each with its own petty history, 'my' cat, 'my dog'" and fault them for inviting us to regress and drawing us "into a narcissistic contemplation." See Deleuze and Guattari, p. 240.

98 Liu, p. 149.

99 Baker, «What Does Becoming-Animal Look Like? », p. 68, p. 89, and p. 95.

100 Baker, p. 68.

101 Baker, p. 88. The animal-made mark, to name but a few, "may take the form of prints or urine stains left on an image by a bear or an elephant, or of chunks bitten of by a wolf or a shark, or may simply be the muddy trace of an anaconda that has moved across a painting." See Baker, p. 88.

102 Baker, p. 88.

103 Baker, pp. 95-96.

104 Ronald Barthes, tr. Richard Howard, Camera Lucida: Reflections on Photography, London, Vintage Books, 2000, p. 96.

105 Barthes, p. 96.

106 Baker, p. 86 and p. 96.

107 Baker, p. 95.

108 Baker, p. 95 .

109 See particularly Liu, pp.81-82 and p. 173.

110 Liu, p. 29.

111 Baker, p. 95 .

112 Liu, pp. 78-79 and p. 89.

113 Arluke and Sanders, p. 67.

\section{Pour citer cet article}

Référence électronique

Tsung-Huei Huang, « Anthropomorphism or Becoming-animal? Ka-shiang Liu's Hill of Stray Dogs as a Case in Point ", Transtext(e)s Transcultures 跨文本跨文化 [En ligne], 5 | 2009, document 9, mis en ligne le 08 avril 2010, Consulté le 08 avril 2010. URL : http://transtexts.revues.org/index279.html

\section{Auteur}


National Taiwan University

Droits d'auteur

(ㄷ) Tous droits réservés 